\title{
Apocrine Cell
}

National Cancer Institute

\section{Source}

National Cancer Institute. Apocrine Cell. NCI Thesaurus. Code C43374.

A glandular secreting cell in which the apical portion of the secreting cell is cast off along with the secretory products that have accumulated therein. 